\title{
English /r/ in L2 and Pidgin/Creole Languages
}

\author{
Ahmed Mousa ${ }^{1}$ \\ ${ }^{1}$ Faculty of Arts and Humanities, King Abdulaziz University, Jeddah, Saudi Arabia \\ Correspondence: Ahmed Mousa, Faculty of Arts and Humanities, KAU, Jeddah 21421, P.O.Box 80202, Saudi \\ Arabia. E-mail: aimousa2004@yahoo.com
}

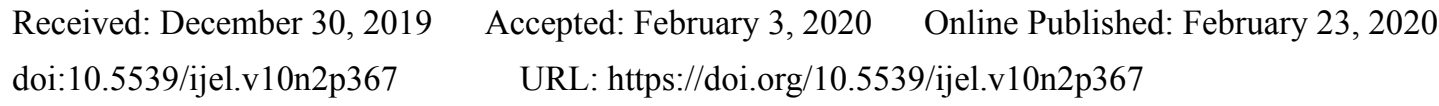

\begin{abstract}
This study aims to investigate how Arab L1 learners of English and speakers of the Broad Jamaican Creole cope with the production of the approximant / $\mathrm{r} /$ preconsonantly, post vocalically and in Stop $+\mathrm{r} /$ clusters, according to the RP norm. To this end, a list of words containing the approximant in the above three environments was given to the two groups, to read. Their production was tape recorded and transcribed. The approximant was nearly totally produced as trill in the three environments by the Arab learners, though one learner managed to produce an American-like $/ \mathrm{r} /$ in addition to the trill. On the other hand, the Jamaican informants produced the approximant according to the RP norm and as an American-like /r/. Whereas Lass's (1984) assumption regarding the preference for trills proved to be true for the Arab learners, it was not the case with the Jamaican informants, in whose production trill was entirely absent. The study also provided further support to the view that phonological acquisition is achieved by gradual reinforcement of motor patterns.
\end{abstract}

Keywords: preconsonantal /r/, postvocalic /r/, stop+/r/ clusters, Arab learners, Broad Jamaican Creole, trill /r/

\section{Introduction}

Among the consonants in the phonemic systems of the world's languages, $/ \mathrm{r} /$ - like sounds received considerable attention in both L1 and L2. They tend to be acquired late (Jakobson, 1968) and are not pronounced correctly until the age of six, (Sanders, 1972). Moreover, /r/ comes as the latest in the order of consonantal acquisition in aphasic children (Winitz, 1969) and children who are adventitiously deaf (Zimmerman et al., 1984). In most languages a common substitution for $/ \mathrm{r} /$ is the glide [w] (Strange \& Browen, 1980; Ferguson, 1973; Barton, 1976), among others. For instance, native English children were found to substitute [w] for /r/ in both perception and production (Strange \& Browen, ibid). The next most common candidate used as a substitute for this sound is [1]. This has been noted by numerous researches of child language, (Ross, in Ingram, 1974; Von Raffler-Engel, 1973; Ruke-Dravina, 1973), regarding L1 English, L1 Italian, L1 Czech and Latvian, respectively. Finally, Smith (1973) reports a further less common substitution. Here, the child produced $/ \mathrm{r} /$ as $[\mathrm{d}]$ in the pronunciation of the word round.

In fact, / $/ \mathrm{r}$ / sound is among apical consonants which are produced with the tip of the tongue against the upper teeth or the alveolar ridge. They can be a stop (e.g., [d]), a nasal [n], a lateral [1] or a flap [r]). In a number of African languages (which are the substrate languages of pidgins and creoles) these sounds are related "either as allophones or as the distinctive parts of allomorphs or as corresponding sounds in different dialects of the same language" (Holm, 2000, p. 161). For instance, the perfective marker in Bambara, a West African language, has the allomorph -ra, -la and -na. Twi /r/ corresponds to /l/ in other Akan/Fanti dialects, and in Ewe, spoken in the Cameroon, [1] and [r] are in complementary distribution (see Holm, 2000 for details). Thus, Liberian English manifests various kinds of alternation between [1], [d] and [n], which all vary with [r]. Likewise, In Surinamese varieties of Creole English, /1/ and /r/ merged as /1/ word -initially, e.g., lobi 'love; rub'. Finally, the English creoles of the Caribbean retain a few remnants of the earlier alternation between $/ \mathrm{r} /$ and $/ 1 /$, as in Miskito Coast creolized English flitaz 'fritter' or Bahamian creolized English ling 'ring'. This being the case, then one would expect to come across discrepancies between the pronunciation of pidgin/creole speakers and that of native speakers of RP, with respect to /r/ sound.

Despite its importance in linguistic behaviour, L2 phonology has received little attention in the literature of second language acquisition, which is replete with analyses relating to the other areas of grammar. Moreover, phonology, according to Arends et al. (1995) and Singh and Muysken (1995), is a relatively neglected domain in 
pidgin/creole phonology, and a comparison with non-creole linguistics is worth considering.

In this study, we are concerned with how Arab learners of L2 English and speakers of the Broad Jamaican Creole behave with respect to the production of English words containing the approximant $/ \mathrm{r} /$. Specifically, preconsonantal and postvocalic $/ \mathrm{r} /$, together with the same approximant in an initial cluster preceded by a stop sound are investigated. The author is unaware of a similar study, in which the two groups have ever been investigated, with respect to the same topic. In other words, this seems to be the first investigation of its kind.

\section{Review of Literature}

Research on second/foreign language acquisition has pointed to the obvious struggle L2 learners of English encounter with this sound (Zimmerman et al., 1984; Sheldon \& Strange, 1982; Mackain et al., 1981; Miyawaki et al., 1975). To illustrate, L1 Japanese learners of English were found to experience difficulty retracting the tongue body and rounding and protruding the lip for the production of pre-vocalic English / $\mathrm{r}$ / (Zimmerman et al., ibid). According to Moulton (1962), German speakers learning English as L2 tended to produce a uvular/r/ sound instead of a retroflex. The commonest error observed in the speech of Arab learners of English is their indiscriminate use of trill, even by excellent speakers of English, (Mitchell \& El-Hassan, 1989; Mousa, 1994, among others). This is because Arabic /r/ is specifically a trill (Harrell, 1962; Qafisheh, 1977; Ingham, 1971). Verma et al. (1992) investigated the production of English / $r$ / by young speakers of Punjabi/Urdu in Britain. The findings showed that acquisition of this approximant would be achieved gradually, as the learners went through varied realizations of the sound in question. In the production of Stop $+/ \mathbf{r} /$ clusters, Chang et al. (2009) reported that speakers of Japanese and Taiwanese Mandarin could not fully master the coordination of the articulatory gestures between the two consonants in the Stop + liquid clusters. Dupoux et al. (2001) concluded that a great deal of the consonant clusters containing Stop $+/ \mathrm{r} /$, transcribed by Japanese speakers contained an epenthetic vowel between the members of the clusters. Adult native speakers of English learning Spanish revealed further struggle with the approximant $/ \mathrm{r} /$ in their attempt to produce this sound in clusters. In the production of such clusters, as will be clarified in due course, difference of the / $\mathrm{r} /$ type in the two languages led to an unacceptable production of the clusters in question. Moreover, once L2 learning and pidgin/creole languages have always been viewed as following the same pattern of development (Cook, 1993; Schumann, 1978; Bickerton, 1995, among others), the intention in this paper is to answer the following research question: Can Arab L1 learners of English and speakers of the Broad Jamaican Creole produce the approximant $/ \mathrm{r} /$ pre-consonantly, post vocalically and in stop $+/ \mathrm{r} /$ clusters, according to the RP norm?

\section{Data Collection}

A list of words (Appendix A) was given to 20 learners of English as a foreign language in the Department of European languages and Literature at King Abdulaziz University, Jeddah, Saudi Arabia. As can be seen, these words contain the approximant $/ \mathrm{r} /$, post-vocalically, pre-consonantly, and in Stop $+/ \mathrm{r} /$ clusters. They were asked to read the words silently and tell of any unfamiliar words. Most of them were familiar, and those which were not, were explained to them. When they were ready, each learner individually pronounced the words which were tape-recorded. As for the speakers of Broad Jamaican Creole, two gentlemen whom the researcher once lived with in England were taken as informants. They were tape-recorded when pronouncing the words in appendix B. The researcher felt it was necessary to supplement the output of these two informants with findings of other investigations on this creole, such as Wells (1973), Baxter et al. (1997), among others. Appendix A and Appendix $\mathrm{B}$, respectively, display how Arab learners and Jamaican informants produced the approximant in question, in these words.

\section{Results}

All the test words in appendix A were pronounced with trill, irrespective of the environment. This was the case in their attempt to pronounce words such as mark, park, lord, etc., which contain preconsonantal / $r /$. Also, in the pronunciation of words containing post-vocalic /r/, such as far, clever, shower, or words which involve clusters of Stop $+/ \mathrm{r} /$, such as train, cream, pram, etc., the production of trill continued.

It was also noticed that words beginning with Stop $+/ \mathrm{r} /$ clusters were produced by epenthesizing a vowel or a schwa between the members of the cluster. Except for one learner, all Arab learners produced trill when producing the test words. The one learner, however, produced the approximant the way it would be produced in American English. Thus, the bottom line is that none of the Arab learners of English in this study managed to produce the approximant concerned according to RP norm, including the one learner mentioned above.

Our Jamaican informants also displayed variation in the production of this approximant. For instance, words which end with -or (doctor, actor) or -er (such as brother, farmer), which contain post-vocalic $/ \mathrm{r} /$ were sometimes 
produced without the final $/ \mathrm{r} /$. The approximant $/ \mathrm{r} /$ was also realized as rhotic after long centralized vowels in monosyllabic words containing preconsonantal /r/, such as first, hurt, shirt, etc. In these words, they produced something that is slightly similar to preconsonantal $/ \mathrm{r} /$ in American English. The articulation of $/ \mathrm{r} /$ in these words starts just after that of the first consonant, in such a way that one perceives the vowel (i.e., nucleus of syllable) $\mathrm{r}$-coloured. Apart from the above processes of the production of $/ \mathrm{r} /$, pre-consonantal $/ \mathrm{r} /$, was produced and dropped in an unsystematic fashion, and this happened even within the same lexical item. To illustrate, both informants produced the word car with postvocalic /r/, but they also pronounced it without the approximant. The word therefore was produced by one of the informants as having $/ \mathrm{r} /$ in the first syllable but not in the second. Then the same word was produced again by the same person, but this time without $/ \mathrm{r} /$ in the first syllable but with $/ \mathrm{r} /$ in the second syllable. This variable pronunciation of preconsonantal $/ \mathrm{r} /$ would prevent one from drawing any conclusion in this connection. As for pronunciation of words containing Stop $+/ \mathrm{r} /$ clusters, our informants did not seem to have any problem. Almost all clusters in their speech were produced according to the RP norm. Moreover, trill was not detected in their production.

\section{Discussion}

As indicated earlier, our Arab learners, almost all of them, produced trill when pronouncing pre-consonantal $/ \mathrm{r} /$ in the words displayed in Appendix A., except for one learner with respect to the words mark, march, park, and lord. In his speech, these words were produced just the same way as in American English, which means that the sound is still rhotic. In other words, our learners are still far from the RP norm regarding the production of the approximant in question. The same behaviour of substituting the RP sound with the L1 (i.e., trill) is witnessed in our learners' attempt to produce words such as far, shower, clever, father, etc., which contain post-vocalic /r/. Again, the same one learner mentioned above in the case of pre-consonantal $/ \mathrm{r} /$ managed to produce this sound the way it is produced in American English.

On the one hand, it is obvious that by producing this trill, they were transferring their L1 articulation to English. On the other hand, the learner who produced a different $/ \mathrm{r} /$ in the pronunciation of such words as far, shower, etc., seems to be pointing to the fact that the target pronunciation is achieved gradually. That is, although there was no single case where he produced an RP-like $/ \mathrm{r} /$ in the two environments, the production of an American-like / $\mathrm{r} /$ in his speech is, perhaps, signalling one step in the direction of an RP-like behaviour.

As mentioned earlier, our Jamaican informants manifested a similar irregularity in the production of $/ \mathrm{r} / \mathrm{in}$ the two environments in question (Appendix B). As we can see from the appendix, one cannot decide exactly when $/ \mathrm{r} /$ is produced and when it is not. This variable pronunciation of $/ \mathrm{r} /$ in these contexts seems to be the trend among the speakers of Jamaican Creole. For instance, this semi-rhoticity is responsible for the dropping of $/ \mathrm{r} /$ at an end of unstressed syllables in words like letter and mother (Wells, 1973) and before a consonant in such words as beard and park, but not when it occurs in a stressed syllable at the end of a word, as in jar, four, chair, etc. (Wells, 1973).

Moreover, certain words are reported to have one fixed pronunciation. For example, the $/ \mathrm{r} /$ in the word over is never pronounced in any variety of Jamaican Creole (i.e., basilect, low mesolect, high mesolect, or acrolect) but the one in dere or there is. One may be tempted to ascribe this behaviour to influence from some speakers of another variety of English our informants may have contact with. For instance, the same phenomenon of semi-rhoticity is displayed by speakers of another variety of English which has been described as having historical connection with creoles. Indeed, it is considered as a post-creole variety. That is, African American Vernacular English (AAVE, henceforth). In this variety, which is known as rhotic, words such as bird, zipper, dear, and car are pronounced as [b3:d, zıpə, dıə, ka:, respectively] (Bailey \& Thomas, 1998; Pollock \& Berni, 1996; Rickford, 1999).

Notice that the approximant $/ \mathrm{r} /$ is not produced in the environments under investigation. According to Sindell (2009), in some varieties of AAVE (e.g. in the southern US), /r/ is not pronounced after the vowels $/ \mathrm{o} / \mathrm{and} / \mathrm{u} /$. Thus, the words door and doe, four and foe and sure and show can be pronounced alike.

As we have seen above, our informants are just like the speakers of AAVE, in that they are inconsistent with regard to the pronunciation of $/ \mathrm{r} /$. But this irregularity in the pronunciation of $/ \mathrm{r} /$ is also witnessed in the speech of other Jamaicans (Rosenfelder, 2009; Wells, 1982, 1973; Mousa, 1994, among others). According to Wells (1980), one should acknowledge variability in the pronunciation of post-vocalic $/ \mathrm{r} /$. Wells also suggests that it is not uncommon for $/ \mathrm{r} /$ to be dropped pre-consonantly in Jamaican creole. Thus, in Jamaica, " $/ \mathrm{r} /$ is much more consistently present in far and near than in start, beard, and letter" (Wells, 1982, p. 221). Then, we should not be surprised to come across the variable pronunciation of this phoneme by our informants. Bailey (1966, p. 1), commenting on this behaviour adds "a given speaker is likely to shift back and forth from Creole to English or 
something closely approximating English within a single utterance, without ever being conscious of this shift". Then what prompts this rhotacization in the non-rhotic Jamaican Creole?

Wells (1973) suggests American influence brought home by workers, students, American tourists, or even radio broadcasts. On the other hand, Rosenfelder (2009) refers this rhoticity to the fact that the early settlers and later immigrants to the New World were speakers of the non-standard British dialects, notably speakers of the rhotic Scottish English. Moreover, many early settlers arrived from Barbados, hence the influence of the only West Indian rhotic accent (Holms, 2000). The genesis of Jamaican Creole is also expected to have exerted some influence. That is, this creole, like many other creoles, is originally non-rhotic, probably due to either lack of rhotic phonemes or the fluctuation between /r/ and /1/ in many West African languages (Holm, 2000; Parkwall, 2000). Thus, absence of rhoticity or the above-mentioned fluctuation may be the cause of this inconsistency in the production of this approximant in the speech of the Broad Jamaican Creole, including our informants.

Also, it seems that this sound is naturally marked in that its mastery is not categorical. For instance, Verma et al. (1992) report a further case of inconsistency in the pronunciation of $/ r /$ regarding these two environments. This time the data comes from the speech of Punjabi Urdu (P-U henceforth) speaking children learning English as a second language in Britain. The subjects of this study were divided into two groups: those who studied English in Yorkshire and those who received formal instructions in Edinburgh. One fact about P-U is that all orthographic $/ \mathrm{r} / \mathrm{s}$ are pronounced in this language. In other words, $/ \mathrm{r} /$ sound in P-U is rhotic.

According to this study, all pre-consonantal $/ \mathrm{r} /$ in the P-U Yorkshire English were produced as non-rhotic and all post-vocalic $/ \mathrm{r} /$ - except two-were produced as rhotic. On the other hand, the P-U Scottish English speakers produced the pre-consonantal $/ \mathrm{r} /$ as rhotic except the one in person. Likewise, all post-vocalic $/ \mathrm{r} /$ were produced as rhotic except the one in there. Once Yorkshire English is non-rhotic, one would easily ascribe the rhotic accent in the speech of the P-U speakers in Yorkshire to transfer from L1, whereas the behaviour of the P-U speakers in Edinburgh may be ascribed to influence from either P-U or Scottish English, since both languages are rhotic. But even when the learners produced rhotic/r/, they did not show consistency. As reported by Verma et al., this rhotic sound varied from an alveolar roll or trill to an alveolar flap to a post-alveolar fricative. According to Verma et al. (1992), /r/ is unusually produced as a weak roll or a flap in P-U and that the influence behind the roll produced in the Edinburgh data is likely to be P-U, rather than Edinburgh English, as a roll is now rarely heard in Edinburgh speech.

The target pronunciation (i.e., RP/r/ in the two environments) was also achieved, though the P-U speakers in Yorkshire showed more consistency in the use of this variety of $/ \mathrm{r} /$ than those in Edinburgh. Thus, one would conclude that RP realization of pre-consonantal /r/ and post-vocalic /r/ is, perhaps, marked and, therefore, it is achieved in a peacemeal fashion. Another conclusion is that the role of the environment of acquisition is undeniably crucial.

It seems that one of the most probable explanation for our Arab learners' inclination to produce the $\mathrm{RP} / \mathrm{r} /$ in the environments in question as trill, is to consider influence from their mother tongue, Arabic, and the input received in class. As we mentioned earlier, Arabic/r/ is noticeably trill, and most learners of English are taught by local teachers who themselves need to master English /r/. This may explain why our learners produced the test words with trill, regardless of the environment. However, the American-like pronunciation of the one learner may be explained in terms of contact with speakers of American English or, perhaps, as a result of watching American films. In both cases one may take it that the leaner is motivated in that he is gradually moving along the continuum from heavy accent which is realized in the production of trill in the direction of the target RP sound via the American-like articulation.

As for our Jamaican informants, trill was not observed in their speech, unlike our Arab learners or P-U speakers in Verma et al. (1992), for instance. A very simple argument to raise here is that trill is not used in the environment where they lived. Instead, the speech of their surrounding contained an American-like $/ \mathrm{r} /$ and an RP one which they used interchangeably, as indicated in Appendix B.

However, this does not mean that trill is not known to speakers of the Broad Jamaican Creole. There has been an early contact between Haitian Creole and Jamaican Pidgin or Creole which may account for some affinities between the two linguistic systems (Holm, 2000). Moreover, according to Singler (1986), the two most important African language groups which contributed in the formation of Haitian Creole were Mande and Kwa, particularly Bambara-Malinke-Dyula and Ewe-Fon. These are West African languages, and according to some linguists, whenever French is spoken in the formerly slave-exporting areas of West Africa today, French / $\mathrm{r} /$ is replaced almost invariably by trill or flap (Faik, 1979; Lafage, 1990, among others). One would conclude from these lines that the Jamaican Creole is expected to have been exposed to the trill /r/ from two sources, at least: 


\section{West African languages and Haitian Creole.}

All the above argument, coupled with the fact that Bailey (1966) outlines trill / $\mathrm{r} /$ among the phonemic inventory of this creole, will leave no doubt that trill was once pronounced by the speakers of Broad Jamaican Creole. Now we turn to the pronunciation of $/ \mathrm{r} /$ in clusters.

As indicated in Appendix A, most clusters involving Stop $+/ \mathrm{r} /$ were produced by breaking them up by inserting a vowel or a schwa between the two members, in the speech of our learners, and the $/ \mathrm{r} /$ was always trill.

Again, our learner who displayed better performance in the previous environments managed to produce clusters with smooth transition between the stop and the following / $\mathrm{r}$ / (see Appendix A, regarding the pronunciation of brother, bread, pram, etc.).

The same strategy of breaking up the cluster Stop $+/ \mathrm{r} /$ by epenthesis has been reported in Mousa (1994). In this study, Arab learners of English as a foreign language were given consonant clusters of the nature Stop $+/ \mathrm{r} /$ to pronounce. The aim was to see if they were able to devoice / $\mathrm{r} /$ after a voiceless stop and if they were capable of producing a voice onset time (VOT) with the same value of native speakers. Most of the learners produced trill and a significantly shorter VOT than that produced by native speakers in such words as pram, train, craft, etc. Moreover, a detectable gap between the members of the cluster was observed, as it was clear that the learners epenthesized a vowel. What the learners were supposed to do was to devoice the $/ \mathrm{r} /$ sound in this environment and to produce an increased VOT in the preceding voiceless stop (Gimson, 1980; Jones, 1969; Davidsen-Nielson, 1974; Klat, 1975, among others).

Likewise, in the speech of P-U speakers in Verma et al. (ibid), Stop $+/ \mathrm{r} /$ clusters were pronounced in different ways. For instance, the words Bradford, crown, grey, green, brother, and eyebrows were pronounced with flap [r] and without a gap between the members of the clusters. The same speakers produced Bradford and bricks with a native-like post-alveolar fricative, and again without lag between the members of the clusters. Trill was also produced in their speech in the pronunciation of crisps and green, but still without vowel epenthesis. Finally, and in harmony with our learners, the words bricks and green were both produced with an epenthetic vowel between the two members of the cluster and a flap [i.e., $\mathrm{r}]$.

Returning to our Jamaican informants, among the words they pronounced were: bread, prepare, brother, cream, etc., but these clusters were articulated normally. That is, they were uttered the same way native speakers of English would utter them. This behaviour may be ascribed to their contact with native speakers throughout the years in Britain, or that Stop $+/ \mathrm{r} /$ clusters should not pause any problem for them, as they are available in the Broad Jamaican Creole (Wells, 1973). However, this does not mean that these clusters are produced by all speakers of pidgin and creole languages.

For instance, because of their markedness, Stop $+/ \mathrm{r} /$ clusters have also been reported to be simplified by speakers of pidgin and creole languages like any consonant clusters. By way of illustration, in these languages the basic CV structure is common except in a limited number of function words consisting of a single vowel (Holm, 2000). The following are examples of the behaviour of speakers from different pidgin/creole languages with respect to the pronunciation of Stop $+/ \mathrm{r} /$ words.

Table 1. Pronunciation of stop $+/ \mathrm{r} /$ clusters in pidgin and creole languages

\begin{tabular}{llll}
\hline Pronunciation & Gloss & Speaker & Source \\
\hline Guirisse & grease & 19th Century Bislama & Do Couto (2006) \\
Piriwa & priwà (French arrow) & Saramaccan & \\
giraun & ground & Tok Pisin & \\
garandi & Grande (big) & Portuguese & \\
kiriol & crioulo (creole) & pidgin / creole & \\
birinka & brincar (to play) & & \\
tarbja & tarabalhar (to work) & & \\
pirgisa & preguiça (laziness) & & \\
kuru & cru (raw, uncooked) & & \\
pofesor & professor & & \\
\hline
\end{tabular}

As we can see in the pronunciation of Stop $+/ \mathrm{r} /$ clusters in Table 1, speakers of pidgin and creole languages tend to break up these clusters by inserting an epenthetic vowel between the two members of the cluster. Our Jamaican informants, however, did not do this. Instead, these clusters were produced according to RP norms. It 
seems that contact with RP speakers in England had influenced their speech. In other words, their speech seems to be moving along the continuum, nearing the target RP. Our assumption hinges on the fact that in many learning situations consonant $+\mathrm{r}$ clusters prove to be problematic. By way of illustration, the same tendency of epenthesis witnessed in the speech of our Arab learners and Verma et al.'s subjects have been reported by Chang et al. (2009) of speakers of Japanese and Taiwanese Mandarin in the production of English words containing Stop + liquid. According to Chang et al. (ibid), even high-proficiency Taiwanese Mandarin speakers of English cannot fully master the coordination of the articulatory gestures between the two consonants in the Stop + liquid cluster. Moreover, Dupoux et al.'s (2001) study has concluded that $79 \%$ of the consonant clusters transcribed by Japanese speakers contain an epenthetic vowel between the two consonants of this cluster.

Colantino and Steele (2006, p. 66) report a further challenge L2 learners face with respect to Stop + liquid clusters. This involves adult native speakers of English learning Spanish. In the intermediate learners' speech, "the most common variation was the L1-transferred approximant $[\mathrm{I}]$ followed by apical trills and fricatives". This behaviour suggests that the learners have not mastered the Spanish clusters in question. This is because, although such clusters are alike orthographically and phonologically in the two languages, the realization of the stop and the liquid is phonetically different. That is, whereas in English the liquid is realized as the approximant $[x]$ or as an affricate in some contexts, in Spanish it is realized as the tap [r] which is voiced throughout its articulation. Of course, this voicing is affected in the speech of the English learners, as affrication leads to the target $/ \mathrm{r} /$ devoicing. Also, English Stop + liquid clusters are realized phonetically as uninterrupted sequences, which means that the transition between the members of the cluster is smooth. In Spanish, however, an epenthetic vowel is always pronounced, hence breaking up the cluster in question. According to Colantoni and Steele (2006, p. 67), "epenthesis is a dissimilatory process which serves to increase the articulatory and perceptual difference between the stop and the rhotic". They argue that, once their rhotic changes in manner via fricativization or approximation in the speech of the above English learners of Spanish, the drive towards the process of dissimilation is no longer tender, as the rhotic is less like the preceding stop. Furthermore, Colantoni and Steele propose that English learners' failure to produce the epenthetic vowel in Stop + liquid clusters is due to their inability to come up with the native-like mastery of the Spanish rhotic both in terms of length and voicing. It is worth mentioning that these learners' realization of the rhotics in these clusters also affects the stops before them, rendering them longer than those produced by native speakers. Thus, one would expect that these English learners will be able to master epenthesis in Spanish Stop + liquid clusters only once the phonetic properties of the members of these clusters have been acquired. In a similar vein, it is safe to ascribe our Arab learners' failure to pronounce English Stop + liquid clusters to failure in realizing such phonetic properties. However, be it in Colantoni and Steele (ibid) or Mousa (1994) or the present study, some learners succeed in achieving native-like mastery of the clusters in question. In other words, "native-like attainment of phonetics is possible in L2 acquisition, albeit rarely and only with a small subset of learners" (Colantoni \& Steele, 2006, p. 59). Indeed, only one learner in either their study and the present one managed to achieve native-like performance with respect to the acquisition of Stop + liquid clusters. As a normal practice, it is wise and important to shed light on how L1 children acquire these clusters, as the claim that L1 = L2 is very sound (Cazden, 1972; Ervin-Tripp, 1974; Wode, 1980), among others.

Studies on child language have exhibited that the child drops the liquid in Stop+ liquid clusters at initial stage of acquisition (as indicated in Table 2) (Cruttenden, 1979; Crystal, 1976; Smith, 1973; Locke, 1983; Moskowitz, 1973), and that in the production of these clusters, an intrusive / $/$ / is sometimes heard between the stop and the liquid, which causes a perceptible lack of reliable interfacing of consonants and liquids (i.e., co-articulation between them) even at relatively advanced ages (Smith, ibid) (c.f., Table 2). It would seem likely then, that mastery of these clusters will continue to be refined over several years. In other words, even after they have been acquired, the integration between segments will continue to develop for some time.

Table 2. Child pronunciation of initial consonant clusters (including stop $+/ \mathrm{r} /$ )

\begin{tabular}{lll}
\hline$[$ ki:n] & "clean" & Cruttenden (1979) \\
[bi:n] & "green" & \\
[tern] & "train" & Crystal (1976) \\
[di:] & "tree" & Smith (1973) \\
[wæibin] & "driving" & \\
{$[\mathrm{ki}: \mathrm{m}]$} & "queen" & \\
{$[\mathrm{bu}]$} & "blue" & Locke (1983) \\
[ten $]$ & "train" & \\
\hline
\end{tabular}


Indeed, consonant clusters used less frequently by the child include initial Stop + liquid (Dyson, 1988). The child has been reported to deploy two strategies, namely consonant reduction and epenthesis, in order to deal with this marked sequence. These two strategies are among the phonological processes that can be applied to consonant cluster production, based on the theory of Natural Phonology (Stampe, 1969). Stop + liquid clusters are among the consonant clusters that appear relatively late in child language (Smith, 1973; Templin,1957; Arlt \& Goodban, 1976). The reader is referred to McLeod et al. (2001) for a detailed account of how children from different linguistic backgrounds behave with respect to the acquisition of consonant clusters in general and Stop + liquid clusters in particular. The behaviour of learners in the present study, in Mousa (1994), in Chang et al. (2007), in Dupoux et al. (2001), as well as of pidgin and creole speakers - with respect to Stop +liquid clusters - lends support to the proposition that there are parallels between children's early acquisition and adult cross-linguistic patterns (Ohala, 1999). Here, we are concerned with their use of the strategy of epenthesis in their attempt to pronounce the clusters in question.

In what follows, an attempt is made to explain the above performance of English L2 learners and speakers of Jamaican Creole, with regard to the pronunciation of the approximant in question, based on Sonority Sequencing, Universal Preference for a CV syllable structure, Markedness, or any other principles, as customarily done nowadays. Carlisle (2001) suggests that "universally preferred complex onsets are constructed by selecting a segment lower on the sonority scale and following it with one higher on the scale" (2001, p. 4). Almost all the above clusters abide by this principle in that the onsets consist of a stop followed by a liquid. One would assume that the pronunciation of these sequences will not be difficult. Then what prompts the use of the above strategy of epenthetic vowel? The speakers above (excluding our Jamaican informants) simply resort to this strategy in order to create a CV syllable structure, as it is recognized as an absolute universal in the languages of the world (Clements, 1990; Cairns \& Feinstein, 1982; Battistella, 1990; Belvins, 1995, among others). Vennenman (1988) has convincingly demonstrated that this is historically true. One can also argue that clusters involving Stop $+/ \mathrm{r} /$ are marked, which leads learners to deploy epenthesis as a learning strategy to get by when pronouncing them. For instance, our Arab learners did produce acceptable pronunciation of such words as stop, star, class, school, glass, etc. Similarly, the P-U speakers in Verma et al (ibid) did manage to pronounce the words class, sleep, scarves, etc., without epenthesis. Moreover, sequences involving Stop $+/ \mathrm{r} /$ which are called "increasing sonority clusters" (Berg \& Niemi, 2000) are usually difficult to acquire. According to Berg and Niemi, these clusters were found to be heterosyllabified in Finnish (just like the case with our learners, Verma et al.'s subjects, child language, etc.) but tautosyllibified in German. Child language was also reported to behave in the same way. According to Vanderweide (1994), children acquiring English as their L1 did not start producing tautosyllabic onset clusters until they had acquired the appropriate representation for liquids, which indicates that these clusters are acquired late.

This argument can be employed to justify the difficulty our Arab learners encounter in their attempt to pronounce Stop $+/ \mathrm{r} /$ clusters. That is, English $/ \mathrm{r} /$ is yet to be acquired by these learners. Thus, one would expect them to produce these clusters authentically after they have abandoned their tendency of pronouncing trill and acquired appropriate English /r/. Archibald (1998) argues that the failure of Japanese, Chinese, Korean and Vietnamese to establish the contrast between /1/ and /r/, because they have only one liquid, is behind their failure to pronounce obstruent + liquid clusters. This is another way of saying that mastery of these individual liquids is expected to facilitate the pronunciation of clusters they are part of. Vanderweide (1994) takes it that the child in Smith's (1973) study (i.e., Amahl) was not able to produce consonant clusters involving liquids until he mastered the liquid contrast.

In our Arab learners' case, the contrast meant is the difference between English $/ \mathrm{r} /$ and Arabic trill. That is, once they stop producing trill and adopt English / $\mathrm{r} /$, they are expected to be able to pronounce an acceptable Stop $+/ \mathrm{r} /$ cluster. We have seen, so far, that one salient treatment of these clusters in both child language and adult L2 learners is to resort to the strategy of vowel epenthesis. This may sound at first an instance of transfer only, in the case of our learners, as their language, Arabic, does not allow complex onsets. But the reader will be surprised to come to know that this same strategy is also deployed by L2 learners whose L1 does allow these clusters. In the acquisition of Russian L2 syllable onsets by native speakers of English, the learners have been reported to epenthesize a vowel in such consonant clusters as $p r-, k r$-, tr-, etc., though the clusters do abide by what is known as permissible syllable construction in English (Ostapenko, 2005). That is, the minimal sonority distance between consonants which is two, according to Table 3. 
Table 3. Sonority hierarchy

\begin{tabular}{ll}
\hline Sounds & Sonority index \\
\hline obstruents & 0 \\
nasals & 1 \\
liquids & 2 \\
glides & 3 \\
vowels & 4 \\
\hline
\end{tabular}

According to Table 3, a word such as drink which begins with a Stop + liquid cluster is illustrated in Figure 1.

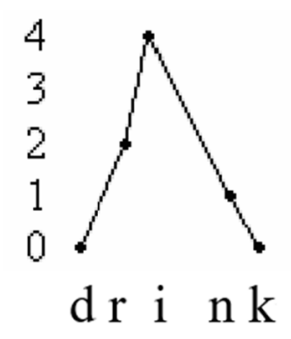

Figure 1. Sonority index

It is clear that the syllable in this word begins with a voiced obstruent which has the lowest sonority $(0)$ and is followed by the more sonorous liquid with number (2) sonority degree. This is a well-formed English syllable, yet the English learners in Ostapenko's (2005) study resort to vowel epenthesis in order to pronounce Russian words of the same nature. This treatment, in Ostapenko's (2005, p. 147) sense would support the learners' "preference for the typologically unmarked syllable structure: CV". To explain what exactly happens on the part of the learners, Ostapenko employs the Optimality Theory (OT) (Prince \& Smolensky, 1993), which views phonological systems as a matter of rankings of universal constraints. Thus, although the sonority distance between the stop and the liquid is 2 in the Russian words (which English does allow), the learners epenthesize a vowel to break up the clusters, in order to avoid violating * Complex, the constraint which states that: no more than one C or V may associate to any syllable position node (Prince \& Smolensky, 1993). In other words, the output in which an epenthetic vowel is used represents the optimal candidate among the several choices in the interlanguage (IL). Consider the ranking of the English word "presumptive" shown in the following tableau (From Ostapenko, 2005). The choice that violates the lowest ranked constraints is indicated by

Table 4. Ranking of the English word "presumptive"

\begin{tabular}{lcccl}
\hline pri-zump-tiv/ & OSon & Dep & Max & $*$ Complex \\
\hline pri-zum-pi-tiv & & $* !$ & & $*$ \\
priz-um-ptiv & $* !$ & & & $*$ \\
pri-zum-ptiv & $* !$ & & & $*$ \\
pri-zump-tiv & & & $* !$ & $*$ \\
pri-zum-tiv & & $* !$ & & \\
pi-ri-zum-pi-tiv & & & & \\
\hline
\end{tabular}

The reader will notice that the Faithfulness constraints are ranked lower than Markedness constraints in that the cluster Stop + liquid is broken up by creating a CV syllable., which indicates that the last realisation of the word in the tableau is the optimal candidate. This is how Arab learners of English treat English words beginning with the cluster Stop $+/ \mathrm{r} /$.

As for our learners in the present study, almost all of them epenthesized a vowel to break up the Stop + liquid clusters given, in the same way as Ostapenko's English learners, with the exception of one learner. But their behaviour should be accounted for in two different ways: L1 transfer and CV preference. That is, once Arabic does not allow complex onsets, use of epenthesis may be interpreted as a matter of mother tongue influence, 
according to which the learners seem to have modified the illicit syllable structure to conform it to the pattern of Arabic, a CV language. But once our learners managed to pronounce words containing initial CC-syllables, such as stop, star, class, glass, etc., as mentioned earlier, one would expect them to treat words with initial Stop + liquid in the same manner. As we have seen, almost all our learners produce these clusters with an epenthetic vowel. Perhaps their success with the other clusters is due to their familiarity with them. We can also add that Stop + liquid clusters are marked compared to the other types. This is why, perhaps, even native speakers (children as well as adults) - as we have seen above - resort to epenthesis. In addition to markedness, preference for a CV syllable is another possible explanation for the above treatment of Stop + liquid clusters on the part of native speakers and L2 learners. Generally speaking, "a liquid would be the least preferred segment in the onset, while a stop would be the most preferred" (Barlow, 2003, p. 187). This means that the combination of the two sounds would not constitute an ultimate cluster. Indeed, the pronunciation of this cluster by the child is a good indicator. Three realizations have been reported to shape the child's pronunciation: modification of the $/ \mathrm{r} /(\mathrm{r} \rightarrow \mathrm{w})$, reduction of the cluster to the stop, and use of epenthetic vowel (Hawkins, 1976; Smith, 1973, among others). Wode (1978) also points to use of uvular [R] by Rigit as preference. This appears in her and other children's pronunciation of such words as reading, right, trinity, drink, etc. In addition to this, the children also make use of frictionless continuant and retroflex types to pronounce the same words. As for adults, we have seen that pronunciation of Stop + liquid clusters is variable. Most Arab L2 English epenthesize a vowel and produce trill (Mousa, 1994 and present study). Use of epenthesis in stop + liquid clusters is also characteristic of the speech of L1 Spanish speakers, Japanese and Taiwanese L2 English learners and English based pidgin and creole languages. This being the case, one would not hesitate to take it that these clusters are marked. This is why only one learner managed to come up with authentic pronunciation in both Colantoni and Steele (2006) and present study. Thus, in corroboration with Colantoni and Steele (2006, p. 59), we propose that "the greater the degree of variability in the phonetic realization of a given parameter, the more difficult it will be to acquire". The variable performance witnessed in the speech of our learners and perhaps our informants with respect to the pronunciation of approximant /r/ may lend support to Khattab's (2002) findings. She investigated the production of $/ \mathrm{r} /$ by English-Arabic bilingual children in Yorkshire, England. She found out that the children "mainly produced approximant types of $/ \mathrm{r} /$ in English, whereas they mainly produced taps and trills in Arabic. Moreover, their accent in English was mainly non-rhotic, whereas in Arabic $/ \mathrm{r} /$ was produced in all pre-and post-vocalic positions" (p. 112). Khattab (2002) suggests that her findings may be interpreted in terms of the recent phonetic and sociolinguistic work on monolingual acquisition which claims that the child is not exposed to a simple stable phonological model; rather, the input the child receives may encompass considerable variability that is not only phonological/allophonic, but may also relate to the social characterisation of the interlocutor (sex, age, social class, etc.), hence rendering variability in the child's input. The bilingual child, as indicated by Foulkes et al. (1999), would face an added degree of variability as s/he is exposed to input that may vary between standard, non-standard, and non-native speech varieties. The Urdu L1 children in Verma et al.'s (1992) study can also be viewed as having been exposed to various realizations of $/ \mathrm{r} /$ types. One would like to argue that the variability seen in the pronunciation of our Arab learners and, perhaps, in the speech of the Jamaican informants, in the production of $/ \mathrm{r} /$, is also due to their exposure to different $/ \mathrm{r} /$ types in the environment where they lived.

The pronunciation of all the above speakers, thus, clearly suggests that Faithfulness constraints are ranked lower than Markedness constraints, and that the optimal realization of an initial Stop + liquid cluster is the one in which an epenthetic vowel is inserted to break up the CC, exactly the same way our learners have displayed in their attempt to pronounce the test words. But L2 learners do not fail completely to come up with native-like realizations of the novel system. For instance, in Mousa (1994), a number of learners (mainly advanced ones) managed to produce English Stop + liquid clusters in such a way that their performance was indistinguishable from that of native speakers. Likewise, in each of Colantoni and Steele (2006) and present study one advanced learner was found to produce native-like attainment in L2 acquisition of Stop + liquid clusters. However, this should not come as a surprise, since L2 learners often do gain success in achieving pronunciations closer and closer to target language norms (Dickerson, 1974; Flege, 1980; Borden et al., 1983). The better performance of these learners could be ascribed, perhaps, to their attendance to the phonetic material that distinguishes sounds in L1 and L2 (Odlin, 1989). In other words, we assume that these learners have perceived the phonetic difference between $\mathrm{L} 1 / \mathrm{r} /$ sounds and L2 ones, as a result of more exposure to this sound in the novel language (Miyawaki et al., 1975; Mackain et al., 1982; Sheldon et al., 1982).

Thus, it is clear from the above account that this approximant poses a learning problem to Arab learners of English irrespective of the environment. We have seen that all learners - except one-have produced trill in their attempt to pronounce the test words. Also, in the two environments where $/ \mathrm{r} /$ is not pronounced in RP (namely pre-consonantally and post-vocalically), the same behaviour of producing a trill variant is manifested, which 
indicates that acquisition has not yet taken place. Moreover, our Arab learners are unable to come up with authentic production of Stop $+\mathrm{r}$ clusters, in that they still produce clear trill which does not allow for smooth transition between the stop and the liquid, consequently this necessitates use of epenthesis. However, as we have seen above, our learners are not alone in their endeavour to articulate this English L2 sound. We have seen children acquiring L1 /r/ sounds, L2 learners of English from different linguistic backgrounds as well as speakers of pidgin and creole languages meander for some time before they produce the target sound. Shih (1996, p. 2223) points rightly to this, noting that " $\mathrm{r}$ in general is a sound that shows tremendous amount of variation in any language". For instance, Wode (1988) reports that German speaking children acquired English $/ \mathrm{r} / \mathrm{in}$ the following stages:

Stage I is typified by substituting uvular trill [R]; Stage II by substituting [w]; Stage III by 'coronal frictionless continuant' [x]; and IV by an L2 target-like retroflex [r].

Similarly, child L1 would display the same gradual acquisition of /r/ sounds. Ruke-Dravina (1973) provides the following chronological sequence of substitutes for Latvian $/ \mathrm{r} /$ :

$$
\mathrm{h} \rightarrow \mathrm{l} \rightarrow \mathrm{ch} \rightarrow / \mathrm{r} / \text { omitted } \rightarrow \text { pause instead of } / \mathrm{r} / \rightarrow \text { uvular trill } \mathrm{R} \rightarrow \mathrm{l} \rightarrow \mathrm{t} \rightarrow \mathrm{r}
$$

According to Jakobson (1968)/r/-like sounds tend to be acquired late, and are not pronounced correctly until the age of six (Sanders, 1972).

The wide range of variation in the pronunciation of this sound indicates its markedness, and the difficulties learners of English $/ \mathrm{r} /$ (and perhaps of other $/ \mathrm{r} /$ 's) encounter are probably due to its complexity, both articulatorily and acoustically (see Gimson, 1980; Ladefoged, 1982). /r/-type sounds are difficult to describe, in the sense that they occupy a range of articulatory positions, some of which are the following:

$\begin{array}{lll}\text { - } & \text { dental/alveolar trill } & \text { (Spanish) } \\ - & \text { dental/alveolar flap } & \text { (Italian) } \\ - & \text { retroflex/approximant } & \text { (English) } \\ - & \text { retroflex/flap } & \text { (Malayan) } \\ -\quad & \text { retroflex/fricative/glide } & \text { (Mandarine) } \\ -\quad \text { palato-alveolar trilled fricative } & \text { (Czech) } \\ -\quad \text { Uvular trill } & \text { (French, German) } \\ - & \text { Uvular fricative. } & \text { (French, German) } \\ - & & \text { (Spencer, 1995) }\end{array}$

\section{Conclusion}

One objective of this work is to investigate whether or not our informants and learners' behaviour would lend support to the claim that "the manner preference for non-laterals appears to be for trills" (Lass, 1984, p. 159). The approximant $/ \mathrm{r}$ / was produced as trill in the entire speech of Arab learners. Our informants' performance, however, with respect to use of $/ \mathrm{r}$ / in the above environments was almost in accordance with the RP norm (which lacks trills) except that it contained instances of American-like pronunciation. In other words, our informants did not make use of trill in their speech at all. This means that Lass's (1984) statement does not apply to them. We have ascribed this to influence from American English or Barbadian or any other rhotic accents. We have also mentioned that this American-like / $\mathrm{r} /$ in their speech can also be reminiscent of use of trill. This assumption squares up nicely with Cassidy and Lepage (1980) who point that the approximant / $r$ / of Jamaican English comes in three categories: alveolar trill, flap, or semi-vowel. They also suggest that "there is a greater tendency towards retention of the r-coloration in the Jamaican than in RP, from which it has completely disappeared" (p. xlvii).

This research also aims at verifying whether or not phonological acquisition is achieved by gradual reinforcement of motor patterns (Hawkins, 1976). Though all our Arab learners produced trill in the test words, one learner exhibited a range of $/ \mathrm{r} /$ types in his speech, except that the target $\mathrm{RP} / \mathrm{r} /$ is yet to be acquired. As mentioned earlier, his pronunciation of English / $\mathrm{r} /$ ranged from trill to a slightly trilled sound to a native-like which resembled a retroflex. Likewise, our Jamaican informants manifested a clear variation in that they produced an American-like / $\mathrm{r} /$ as well as an $\mathrm{RP} / \mathrm{r} /$. The behaviour of both groups is best explained in terms of Major's (2001) Ontogeny Phylogeny Model (OPM), which views the learner's interlanguage (IL) as containing components from the learner's first language (L1), the second language (L2), and universals of language that are not already part of the L1 or L2 system (See Major 2001). 
The reader will notice that in all the above situations (i.e. L1 acquisition) L2 (including the state of bilingualism) and pidgin/creole languages, speakers go through various pronunciations before target $/ \mathrm{r} /$ sounds are mastered, hence corroborating the position that phonological acquisition is achieved by gradual reinforcement of motor patterns (Hawkins, 1976; Major, 2001; Wode, 1981) among others.

\section{Acknowledgements}

This research was made possible through a grant from the Deanship of Scientific Research, King Abdulaziz University, Jeddah, Saudi Arabia (Project No 429/031-2). The author wishes to acknowledge that.

\section{References}

Archibald, J. (1998). Second language phonology. Amsterdam: John Benjamins. https://doi.org/10.1075/lald.17

Arends, J., Muysken, P., \& Smith, N. (1995). (Eds). Pidgins and creoles: an introduction. Amsterdam: Benjamins. https://doi.org/10.1075/cll.15

Arlt, P. B., \& Goodban, M. J. (1976). A comparative study of articulation acquisition as based on a study of 240 normals, aged three to six. Language, Speech, and Hearing Services in Schools, 7, 173-180. https://doi.org/10.1044/0161-1461.0703.173

Bailey, B. (1966). Jamaican creole syntax. Cambridge: Cambridge University Press.

Bailey, G., \& Thomas, E. (1998). Some Aspects of African-American Vernacular English Phonology. In S. M. Salikoko, R. R. John, B. Guy \& B. John (Eds.), African-American English: Structure, History and Use (pp. 85-109). New York: Routledge.

Barlow, J. A. (2003). Asymmetries in the acquisition of consonant clusters in Spanish. Canadian Journal of Linguistics, 48, 179-210. https://doi.org/10.1017/S0008413100000645

Barton, D. (1976). Phonemic discrimination and the knowledge of words in children under three years. Papers and Reports on Child Language Development, 11, 61-68.

Battistella, E. L. (1990). Markedness: The evaluative superstructure of language. Albany: State University of New York Press.

Baxter, A. N., Lucchesi, D., \& Guimaraes, M. (1997). Gender agreement as a "decreolizing" feature of an Afro-Brazilian dialect. Journal of Pidgin and Creole Languages, 12, 1-57. https://doi.org/10.1075/jpcl.12.1.02bax

Berg, T., \& Niemi, J. (2000). Syllabification in Finnish and German: onset filling vs. onset maximization. Journal of Phonetics, 28(2), 187-216. https://doi.org/10.1006/jpho.2000.0112

Bickerton, D. (1995). Creole and the bankruptcy of current acquisition theory. In W. Herman (Ed.), Creole languages and language acquisition. Berlin: Mouton De Gruyter.

Blevins, J. (1995). The Syllable in Phonological Theory. In J. Goldsmith (Ed.), Handbook of phonological theory (Vol. 1, pp. 206-244). London: Blackwell. https://doi.org/10.1111/b.9780631201267.1996.00008.x

Borden, G., Gerber, A., \& Milsark, G. (1983). Production and perception pf the /r/-/1/ consonants in Korean adult learners of English. Language Learning, 33, 499-526. https://doi.org/10.1111/j.1467-1770.1983.tb00946.x

Cairns, C., \& Feinstein, M. (1982). Markedness and the theory of syllable structure. Linguistic Inquiry, 13, 193226.

Carlisle, R. (2001). Syllable structure universals and second language acquisition. International Journal of English Studies, 1, 1-19.

Cassidy, F., \& Lepage, R. B. (1980). Dictionary of Jamaican English. Cambridge: Cambridge University Press.

Cazden, C. B. (1972). Child language and education. New York: Holt.

Chang, B., Haynes, F., Yao, Y., \& Rhodes, R. (2009). A tale of five fricatives: Consonantal contrast in heritage speakers of Mandarin. University of Pennsylvania Working Papers in Linguistics, 15(1), 37-43.

Clements, N. (1990). The role of the sonority cycle in core syllabification. Papers in Laboratory Phonology, 1, 283-333. https://doi.org/10.1017/CBO9780511627736.017

Colantoni, L., \& Steele, J. (2006). Native-like attainment in the L2 acquisition of Spanish stop-liquid clusters. In K. Carol \& F. Timothy (Eds.), Selected Proceedings of the 7th Conference on the Acquisition of Spanish and Portuguese as First and Second Languages (pp. 59-73). Somerville, MA: Cascadilla Press. 
Cook, V. (1993). Linguistics and second language acquisition. Basingstoke: Macmillan. https://doi.org/10.1007/978-1-349-22853-9

Cruttenden, A. (1979). Language in Infancy and Childhood. Manchester University Press

Crystal, D. (1976). Child language, learning, and linguistics. London: Edward Arnold.

Davidsen-Nielsen, N. (1974). Syllabification in English words with medial sp, st, sk. Journal of Phonetics, 2, 15-45. https://doi.org/10.1016/S0095-4470(19)31175-1

Dickerson, L. (1974). Internal and external patterning of phonological variability in the speech of Japanese learners of English. Unpublished Doctoral Thesis, University of Illinois.

Do Couto, H. (2006). Reconstructing Kriol Syllable Structures. PAPIA, 16, 117-125.

Dupoux, E., Pallier, C., Kakehi, K., \& Mehler, J. (2001). New evidence for prelexical phonological processing in word recognition. Language and Cognitive Processes, 16(5/6), 491-505. https://doi.org/10.1080/01690960143000191

Dyson, A. T. (1988). Phonetic inventories of 2- and 3-year-old children. Journal of Speech and Hearing Disorders, 53, 89-93. https://doi.org/10.1044/jshd.5301.89

Ervin-Tripp, S. M. (1974). Is second language learning like the first? TESOL Quarterly, 8, 111-125. https://doi.org/10.2307/3585535

Faik, S. (1979). (Ed.) Le francçais en Zaire. In Le français hors de France (pp. 441-472). Paris: Champion.

Ferguson, C. (1973). Fricatives in child language acquisition. Papers and Reports on Child Language Development, 6, 61-85.

Flege, J. E. (1980). Phonetic approximation in second language acquisition. Language Learning, 30, 119-134. https://doi.org/10.1111/j.1467-1770.1980.tb00154.x

Foulkes, P., Gerardj, D., \& Dominicj, W. (1999). Tracking the emergence of structured variation. Leeds Working Papers in Linguistics and Phonetics, 7, 1-25.

Gimson, A. C. (1980). An Introduction to the Pronunciation of English. London Edward Arnold.

Harrel, R. (1962). A short reference grammar of Moroccan Arabic. Washington DC: Georgetown University Press.

Hawkins, S. (1976). The Developing Organisation of Speech Production in children: evidence from consonant clusters. Unpublished Doctoral Dissertation. The University of Cambridge.

Holm, J. (2000). An introduction to pidgin and creole. Cambridge University Press: Cambridge. https://doi.org/10.1017/CBO9781139164153

Ingham, B. (1971). Some characteristics of Meccan speech. Bulletin of the School of Oriental and African Studies, 34, 273-279. https://doi.org/10.1017/S0041977X00129544

Ingram, D. (1974). Phonology rules in young children. Journal of Child Language, 1, 49-64. https://doi.org/10.1017/S0305000900000076

Jakobson, R. (1968). Child language, aphasia and phonological universals. The Hague Mouton. https://doi.org/10.1515/9783111353562

Jones, D. (1969). An outline of English phonetics. Cambridge: Heffer.

Khattab, G. (2002). /1/ production in English-Arabic bilingual speakers. International Journal of Bilingualism, 3, 335-353. https://doi.org/10.1177/13670069020060030701

Klatt, D. H. (1975). Vowel lengthening is syntactically determined in a connected discourse. Journal of Phonetics, 3, 129-140. https://doi.org/10.1016/S0095-4470(19)31360-9

Ladefoged, P. (1982). A course in phonetics. New York: Harcourt.

Lafage, S. (1990). Afrika. In G. Holtus, M. Metzeltin \& C. Schmitt (Eds.), Lexikon der romanistischen Linguistik (vol. 5, pp. 767-768). Tùbingen: Max Niemeyer Verlag.

Lass, R. (1984). Phonology: an introduction to basic concepts. Cambridge: CUP.

Locke, J. (1983). Phonological acquisition and change. New York: Academic Press.

Mackain, K., Best, C., \& Strange, W. (1981). Categorical perception of English /r/ and /1/ by Japanese bilinguals. 
Applied Psycholinguistics, 2, 369-390. https://doi.org/10.1017/S0142716400009796

Major, R. C. (2001). Foreign accent: the ontogeny and phylogeny of second language phonology. Mahwah, NJ and London: Lawrence Erlbaum. https://doi.org/10.4324/9781410604293

McLeod, S., Doorn, J., \& Reed, V. (2001). Normal Acquisition of Consonant Clusters. American Journal of Speech-Language Pathology, 10, 99-110. https://doi.org/10.1044/1058-0360(2001/011)

Mitchell, T., \& El-Hassan, S. (1989). English pronunciation for Arabic speakers. London: Longman.

Miyawaki, K., Strange, W., Verbrugge, R., Liberman, A., Jenkins, J., \& Fujimura, O. (1975). An effect of linguistic experience: the discrimination of $/ \mathrm{r} /$ and $/ 1 /$ by native speakers of Japanese and English. Perception and Psychophysics, 18, 331-340. https://doi.org/10.3758/BF03211209

Moskowitz, A. (1973). The acquisition of phonology and syntax: A preliminary Study. Approaches to Natural Language, 49, 48-84. https://doi.org/10.1007/978-94-010-2506-5_2

Moulton, W. (1962). Toward a classification of pronunciation errors. Modern Language Journal, 46, 101-109. https://doi.org/10.1111/j.1540-4781.1962.tb01773.x

Mousa, A. (1994). The interphonology of Saudi learners of English. Unpublished PhD Dissertation: University of Essex.

Odlin, T. (1989). Language transfer cross-linguistic influence in language learning. Cambridge: Cambridge University Press. https://doi.org/10.1017/CBO9781139524537

Ohala, J. (1999). There is no interface between phonology and phonetics: a personal view. Journal of Phonetics, 18, 153-171. https://doi.org/10.1016/S0095-4470(19)30399-7

Ostapenko, O. (2005). The optimal L2 Russian syllable onset. LSO Working Papers in Linguistics, 5, 140-151.

Parkwall, M. (2000). Out of Africa. London: Battlebridge.

Pollock, K., \& Berni, M. C. (1996). Vocalic and postvocalic/r/in African American Memphians. Paper presented at the New Ways of Analyzing Variation in English (NWAVE) meeting, Las Vegas, NV.

Prince, A., \& Smolensky, P. (1993). Optimality Theory: constraint interaction in generative grammar. Cambridge, MA: MIT Press.

Qafisheh, H. (1977). A short reference grammar of Gulf Arabic. Tucsion, Arizona: University of Arizona.

Rickford, J. (1999). African American English: Features, Evolution, Educational Implications. Malden, MA: Blackwell.

Rosenfelder, I. (2009). Rhoticity in educated Jamaican English: An analysis of the spoken component of ICE-Jamaica. In T. Hoffmann \& L. Siebers (Eds.), World Englishes-Problems, Properties and Prospects: Selected Papers from the 13th IAWE Conference (pp. 61-82). Amsterdam/Philadelphia: John Benjamins. https://doi.org/10.1075/veaw.g40.07ros

Ruke-Dravina, V. (1973). The process of acquisition of apical /r/ and uvular $/ \mathrm{r} /$ in the speech of children. In C. Ferguson \& D. Slobib (Eds.), Studies of child language development. New York: Holt.

Sanders, E. (1972). When are speech sounds learned? Journal of Speech and Hearing Disorders, 37, 55-63. https://doi.org/10.1044/jshd.3701.55

Schumann, J. (1978). The fundamentals of particle phonology. Phonology Yearbook, 1, 129-155. https://doi.org/10.1017/S0952675700000324

Sheldon, A., \& Strange, W. (1982). The acquisition of /1/ and /r/ by Japanese learners of English: Evidence that speech production can precede speech perception. Applied Linguistics, 3, 343-261. https://doi.org/10.1017/S0142716400001417

Shih, C. (1996). Synthesis of trill (vol. 4, pp. 2223-2226). ICSLP 96, Proceedings, Fourth International Conference on Spoken Language. https://doi.org/10.1109/ICSLP.1996.607247

Sidnell, J. (2009). African American Vernacular English (Ebonics). Language Varieties. University of New England.

Singh, R., \& Muysken, P. (1995). A debate in pidgin/creole phonology. Journal of Pidgin and Creole Languages, 10(1), 157-169. https://doi.org/10.1075/jpcl.10.1.07sin

Singler, J. (1986). Remarks in response to Derek Bickerton's “Creoles and universal grammar: the unmarked 
case? Journal of Pidgin and Creole Languages, 1, 141-145. https://doi.org/10.1075/jpcl.1.1.12joh

Smith, N. (1973). The acquisition of phonology: A case study. Cambridge University Press.

Spencer, A. (1995). Phonology: theory and description. Wiley-Blackwell

Stampe, D. (1969). The acquisition of phonetic representation. In R. Binnick et al. (Eds.), Papers from the Fifth Regional Meeting of the Chicago Linguistic Society (pp. 443-454). Chicago: Chicago Linguistic Society.

Strange, W., \& Browen, P. (1980). Perception and production of approximant consonants by three-year olds: a first study. In K. Yeni et al. (Eds.), Child Phonology (vol. 2, pp. 117-154). Academic Press.

Templin, M. C. (1957). Certain language skills in children (Monograph Series No. 26). Minneapolis: University of Minnesota, The Institute of Child Welfare. https://doi.org/10.5749/j.ctttv2st

Vanderweide, T. (1994). Government phonology and principles of Ll syllabification. University of Calgary. Master's Thesis.

Vennemann, T. (1988). Preference laws for syllable structure and the explanation of sound change: with special reference to German, Germanic, Italian, and Latin. Berlin: Mouton de Gruyter. https://doi.org/10.1515/9783110849608

Verma, K., Firth, S., \& Corrigan, P. (1992). The developing phonological system of Panjabi/Urdu speaking children learning English as a second language in Britain. In J. Leather \& J. Allan (Eds.), New Sounds 92: Proceedings of the 1992 Amsterdam Symposium on the Acquisimon of Second Language Speech (pp. 174199), University of Amsterdam, 13-16 April 1992. Amsterdam: University of Amsterdam.

Von Raffler-Engel, W. (1973). An example of the linguistic consciousness in the child. In C. Ferguson \& D. Slobib (Eds.), Studies of child language development. New York: Holt.

Washabaugh, W. (1977). Constraining variation in decreolization. Language, 53, 329-352. https://doi.org/10.1353/lan.1977.0013

Wells, J. C. (1973). Jamaican pronunciation in London. Oxford: Blackwell.

Wells, J. C. (1980). The brogue that isn't. JIPA, 10, 74-79. https://doi.org/10.1017/S0025100300002115

Wells, J. C. (1982). Accents of English. CUP. Cambridge. https://doi.org/10.1017/CBO9780511611759

Winitz, H. (1969). Articulatory acquisition and behaviour. New York: Appleton-Century-Croft.

Wode, H. (1978). The beginning of non-school room L2 phonological acquisition. International Review of Applied Linguistics in Language Learning, 16, 109-126. https://doi.org/10.1515/iral.1978.16.1-4.109

Wode, H. (1980). Phonology in L2 acquisition. In S. Felix (Ed.), Second language development (pp. 123-136). Tübingen: Narr.

Wode, H. (1981). Learning a second language I. An integrated view of language acquisition. Tubingen: Narr.

Wode, H. (1988). Einführung in die Psycholinguistik: Theorien, Methoden, Ergebnisse. Ismaning: Hueber. https://doi.org/10.1515/east-1988-0190

Zimmerman, G., Price, P., \& Ayusawa, T. (1984). The production of English /r/ and /1/ by two Japanese speakers differing in experience with English. Journal of Phonetics, 12, 187-193. https://doi.org/10.1016/S0095-4470(19)30873-3 


\section{Appendix A}

Pronunciation of $/ \mathbf{r} /$ in the speech of Arab learners

\begin{tabular}{|c|c|c|}
\hline Word & Arab Learners' Pronunciation & $\mathbf{R P}$ \\
\hline Far & $/ \mathrm{fa}:[\mathrm{r}] /, / \mathrm{fa}: \mathrm{r} /$ & /fa:/ \\
\hline Car & $/ \mathrm{ka}:[\mathrm{r}] /, / \mathrm{fa}: \mathrm{r} /$ & /ka:/ \\
\hline October & /Poktoba[r]/,/Ppktəubər/ & /oktəubə/ \\
\hline Father & /fazə[r]/,/fa:ðər/ & /fa:ðə/ \\
\hline Mother & $/ \mathrm{maz}[\mathrm{r}] /, / \mathrm{m} \wedge$ ðər/ & /m^ðə/ \\
\hline Bear & /be:[r]/ & /bea/ \\
\hline March & $/ \mathrm{ma}:[\mathrm{r}] \mathrm{t} \mathrm{f} /, / \mathrm{ma}:[\mathrm{r}] \mathrm{J} /$ & /ma:tf/ \\
\hline Mark & $/ \mathrm{ma}:[\mathrm{r}] \mathrm{k} /, / \mathrm{ma}:[\mathrm{r}] \mathrm{k} /$ & /ma:k/ \\
\hline Lord & $/ \mathrm{lo}:[\mathrm{r}] \mathrm{d} /$ & $/ \mathrm{lo:d} /$ \\
\hline Hard & /ha:[r]d/ & /ha:d/ \\
\hline Shower & / $\mathrm{a} a \partial[\mathrm{r}] /$ & / $\mathrm{Javo/}$ \\
\hline Clever & /kəlıfu[r]/ & /kleva/ \\
\hline Park & $/ \mathrm{pa}:[\mathrm{r}] \mathrm{k} /$ & /pa:k/ \\
\hline Prepare & $/ p \curvearrowright[r] \mathrm{rpe}:[\mathrm{r}] /$ & /pripea/ \\
\hline Brother & /braza[r]/ & /br^ðə/ \\
\hline Crab & $/ \mathrm{k} \partial[\mathrm{r}] \mathrm{ab} /, / \mathrm{kræb} /$ & /kræb/ \\
\hline Cream & $/ \mathrm{k} \partial[\mathrm{r}] \mathrm{i}: \mathrm{m} /$ & /kri:m/ \\
\hline Drop & $/ \mathrm{d} \curvearrowright[\mathrm{r}] \mathrm{pp} /$ & /drop/ \\
\hline Train & $/ \mathrm{to}[\mathrm{r}] \mathrm{e}: \mathrm{n} /$ & /trein/ \\
\hline Gray & /gi[r]e:/, /ge[r]e:/ & /greI/ \\
\hline Gram & $/ \mathrm{gI}[\mathrm{r}] \mathrm{am} /$ & /græm/ \\
\hline Drink & $/ \mathrm{d} \partial[\mathrm{r}] \mathrm{r} \mathrm{n} \mathrm{k} /$ & /drınk/ \\
\hline Great & /ga[r]e:t/, /greit/ & /greit/ \\
\hline Bread & /bə[r]ed/, /bred/ & /bred/ \\
\hline Browse & /bə[r]auz/, /braoz/ & /braoz/ \\
\hline Brown & /bə[r]aon/, /braon/ & /braon/ \\
\hline Pram & $/ \mathrm{p} \curvearrowright[\mathrm{r}] \mathrm{am} /, / \mathrm{b} \curvearrowright[\mathrm{r}] \mathrm{am} /, / \mathrm{præm} /$ & /præm/ \\
\hline
\end{tabular}




\section{Appendix B}

Pronunciation of $/ \mathbf{r} /$ by Jamaican informants

\begin{tabular}{|c|c|c|c|}
\hline Word & Jamaican Informants & JC & RP \\
\hline Church & $/ \mathrm{t} \int_{3} \mathrm{rt} \int /, / \mathrm{t} \int 3: \mathrm{rt} / /$ & $/ \mathrm{t} \mathrm{fo}:[\mathrm{r}] \mathrm{t} \mathrm{g} /$ & $/ \mathrm{t} \int 3: \mathrm{rt} \int /$ \\
\hline Shark & / $\mathrm{a} a: \mathrm{rk} /$ & $/ \int \mathrm{a}: \mathrm{k} /$ & $/ \int \mathrm{a}: \mathrm{k} /$ \\
\hline Doctor & /dpkto/ & /da:kta/ & /dpkta/ \\
\hline Farm & /fa:rm/ & $/ \mathrm{fa}: \mathrm{m} /$ & $/ \mathrm{fa}: \mathrm{m} /$ \\
\hline Word & /wœrd/ & /wo[r]d/ & /w3:d/ \\
\hline Weir & /wi:r/, /we:r/ & /wier/ & /wiə/ \\
\hline Wear & /wi:r/, /we:r/ & /wier/ & /wea/ \\
\hline Were & /wz:r/ & /wo[r] $/$ & /w3:/ \\
\hline Thirty & $/ \theta_{3}:$ rtt/, /te:tr/ & /te:tr/ & $/ \theta_{3}: \mathrm{t} /$ \\
\hline Actor & /ækto/ & /akta/ & /æktə/ \\
\hline Door & /do:r/ & /do:r/ & /do:/ \\
\hline Car & /kja:/, /ka:r/ & /kja:/ & /ka:/ \\
\hline First & /fz:rst/ & /fz:rst/ & /fz:st/ \\
\hline Hurt & /hz:rt/ & /hz:rt/ & /h3:t/ \\
\hline Shirt & $/ \sqrt{3}: \mathrm{rt} /$ & $/ \sqrt{3}: \mathrm{rt} /$ & $/ \sqrt{3}: \mathrm{t} /$ \\
\hline Brother & /brıdə/, /brıdər/ & /brada/ & /br^ðə/ \\
\hline Therefore & /derfo:/,/dz:fo:r/ & /derfo:/ & /ðеəfっ:/ \\
\hline Year & /jiər/, /rer/ & /ji:r/ & /jiə/ \\
\hline Mother & /mudə/,/mıdər/ & /madə/ & /m^ðə/ \\
\hline Bread & /bred/ & /bred/ & /bred/ \\
\hline Crown & /kraon/ & /kraon/ & /kraon/ \\
\hline Cream & /kri:m/ & /kri:m/ & /kri:m/ \\
\hline Trout & /traot/ & /traot/ & /traot/ \\
\hline Train & /tre:n/ & /tre:n/ & $/$ trein/ \\
\hline Trick & /trik/ & /trık/ & /trik/ \\
\hline Crane & /kre:n/ & /kre:n/ & /kreIn/ \\
\hline Proud & /praud/ & /praod/ & $/ \mathrm{praud} /$ \\
\hline Pram & /præm/ & /pra:m/ & /præm/ \\
\hline Prepare & /pripe:r/ & /pripe:r/ & /pripeə/ \\
\hline
\end{tabular}

\section{Copyrights}

Copyright for this article is retained by the author, with first publication rights granted to the journal.

This is an open-access article distributed under the terms and conditions of the Creative Commons Attribution license (http://creativecommons.org/licenses/by/4.0/). 